\title{
The effect of probiotic Bacillus amyloliquefaciens on growth performance, immune organ index and immune function of weaned meat rabbits
}

\author{
Hongna Zhang ${ }^{1 \#}$, Jingbo Liü ${ }^{2 \#}$ Zengmin Miao ${ }^{3 *}$ \\ ${ }^{1}$ Department of Teaching Affairs, Hebei University of Economics and Business, Shijiazhuang City, China \\ ${ }^{2}$ School of Animal Science and Technology, Shandong Agricultural University, Tai'an City, China \\ ${ }^{3}$ School of Life Sciences, Shandong First Medical University, Tai'an City, China
}

ZHANG, H., J. LIU, Z. MIAO: The effect of probiotic Bacillus amyloliquefaciens on growth performance, immune organ index and immune function of weaned meat rabbits. Vet. arhiv 90, 271-277, 2020.

\section{ABSTRACT}

Bacillus has been reported to improve the production performance and immunity of chickens and pigs, so we hypothesized that Bacillus amyloliquefaciens (BA) could effectively increase the growth performance and immunological ability of weaned meat rabbits. To verify this hypothesis, this study was designed to examine the effect of BA on the growth performance, immune organ index, and immune function of meat rabbits. A total of 160 weaned New Zealand meat rabbits ( $35 \pm 3$ days) were randomly divided into 4 groups with 4 replicates per group $(\mathrm{n}=10$ per replicate, 5 males and 5 females). The rabbits of the control group were fed with a basal diet and the rabbits of treatment groups I, II and III were fed with the basal diet supplemented with 150, 300 and $450 \mathrm{mg} / \mathrm{kg}$ BA, respectively, for a total of 8 weeks. Our results showed that BA supplementation increased daily gain and reduced feed to gain ratio. Furthermore, BA supplementation significantly increased splenic and thymic indexes and the levels of immunoglobulin $\mathrm{M}(\mathrm{IgM})$, complement $3(\mathrm{C} 3)$, and $\mathrm{C} 4$ in the treatment groups II and III $(\mathrm{P}<0.05)$. Therefore, BA supplementation in the diet could effectively improve the growth performance, immune organ index and immune function of weaned meat rabbits.

Key words: Bacillus amyloliquefaciens; meat rabbits; growth performance; immune organ index; immune function

\#These authors contributed equally to this work

\section{Introduction}

The wide use of antibiotics in livestock farming may bring about many positive outcomes, including improved animal production performance and reduced disease (DOWARAH et al, 2017; GADDE et al., 2017). Irrational or abusive use of antibiotics, however, has also led to several problems, such as occurrence of antibiotic-resistant bacteria, a weakened immune system, antibiotic residual in animal-origin foods, and environmental contamination (BARTON, 2000; GAO et al., 2017; LI et al., 2017; ZOU et al., 2016). To tackle these problems, many countries have developed regulations and restrictions on antibiotics as feed

\footnotetext{
*Corresponding author:

Zengmin Miao, School of Life Sciences, Shandong First Medical University, Changcheng Road 619, Gaoxin District, Tai'an City 271000, China, Phone: +86 0538622 9953; Fax: +86053 8622 9953; E-mail: mzm1218@126.com; zengminmiao@126.com
} 
supplements (COGLIANI et al., 2011). Therefore, the search for a highly effective, non-toxic, residualfree and safe feed product, as a substitute for antibiotics, has become the major focus of animal nutrition studies (YANG and MCHOCT, 2009).

A probiotic is a new type of functional feed additive that is safe, non-toxic, and residual-free, and has many healthy functions, such as disease prevention and growth promotion, and is hence a promising effective substitute for feed antibiotics (LUTFUL KABIR, 2009). Bacillus is an acidtolerant, salt-tolerant, heat-tolerant, and stable probiotic, and its biological function is mainly derived from its ability to generate numerous bio-active substances, such as proteases, lipases, and amylases, as well as antimicrobial substances that inhibit the growth of pathogenic bacteria and viruses (PARK et al., 2016; GIBSON et al., 2017).

At present, Bacillus has been reported to improve the production performance and immunity of chickens and pigs(GUO etal., 2018; SAMOLINSKA et al., 2018). In addition, the rabbit digestive system and immune system are different from those of pigs and chickens. However, information about the effects of Bacillus on the growth and immune functions of meat rabbit is scant. Therefore, in this study, the daily diet of weaned New Zealand meat rabbits was supplemented with Bacillus amyloliquefaciens (BA) to examine its effect on the growth performance and immune functions of these animals, in order to provide a theoretical and scientific basis for wide application of BA.

\section{Materials and methods}

Ethics statement. Animal experiments in this study were carried out under the supervision of the Animal Care and Use Committee of Shandong Province, China (Permit No. 20181126).

Experimental design. A total of 160 weaned New Zealand meat rabbits (35 \pm 3 days; $782 \pm$ $31 \mathrm{~g}$ ) were randomly divided into a control group and treatment groups I, II, and III, with 4 replicates per group, and 10 rabbits (5 males and 5 females) per replicate. The basal feed used in this study was produced on the basis of the standard Nutrient Requirements of Rabbits (NRC, 1977) (Table 1).
Table 1. Composition and nutrient levels of the basal diet (air-dry)

\begin{tabular}{|l|c|}
\hline Items & Content \\
\hline Ingredients (\%) \\
\hline Alfalfa meal & 30.0 \\
\hline Corn & 21.0 \\
\hline Soybean meal & 10.7 \\
\hline Wheat bran & 21.0 \\
\hline Wheat & 7.0 \\
\hline Silkworm chrysalis & 3.0 \\
\hline Rapeseed meal & 4.0 \\
\hline CaHPO & 0.9 \\
\hline Limestone & 0.7 \\
\hline NaCl & 0.5 \\
\hline Lysine & 0.2 \\
\hline Premix ${ }^{\#}$ & 1.0 \\
\hline Total & 100.0 \\
\hline Nutrient levels & \\
\hline Crude protein & 16.02 \\
\hline Crude fiber & 13.10 \\
\hline Ca & 0.90 \\
\hline P & 0.62 \\
\hline Digestible energy $(\mathrm{DE})(\mathrm{MJ} / \mathrm{kg})^{*}$ & 10.71 \\
\hline Premix provied & \\
\hline
\end{tabular}

${ }^{\#}$ Premix provided the following per $\mathrm{kg}$ of diet: $\mathrm{Cu}, 120 \mathrm{mg}$; Fe, 100 mg; Zn, 90 mg; Mn, 30 mg; Mg, $150 \mathrm{mg}$; vitamin A, 4,000 IU; vitamin $\mathrm{D}_{3}, 1,000 \mathrm{IU}$; vitamin E, $50 \mathrm{mg}$; choline, 1 mg; *DE was calculated (de Blas and Mateos, 1998), and the other nutrient levels were measured values.

The control group was fed with the basal diet, while treatment groups I, II, and III were fed with the basal diet supplemented with 150, 300 and $450 \mathrm{mg} / \mathrm{kg}$ BA (viable bacteria $\geq 1.5 \times 10^{10} \mathrm{CFU} / \mathrm{g}$ ), respectively, for a total of 8 weeks.

All experimental rabbits were housed in a closed rabbit shed, with two rabbits per cage $(60 \mathrm{~cm} \times$ $60 \mathrm{~cm} \times 60 \mathrm{~cm}$ ). The rabbit shed and its ancillary facilities were strictly disinfected prior to the experiment. The experimental rabbits had access to water and food ad libitum, and the rabbit shed was regularly cleaned. At the end of the experiment, the rabbits were anesthetized with $10 \%$ chloral hydrate and then sacrificed for further study. 
Determination of growth performance. During the experimental period, the food consumption and fasting weight of the experimental rabbits were measured weekly. Average daily gain (ADG), average daily feed intake (ADFI), and feed to gain ratio $(\mathrm{F} / \mathrm{G})$ were calculated as follows:

$\mathrm{ADG}=$ Total gain / (Number of rabbits per group $\times$ experimental days $)$, ADFI $=($ Total feed provided-total feed remaining) / (Number of rabbits per group $\times$ experimental days); $F / G=$ Daily feed intake/daily gain.

Determination of immune organ index. At the end of the experiment, 5 experimental rabbits were randomly selected from each group, and the thymus and spleen of each rabbit were weighed to calculate the thymic and splenic index, respectively. Thymic index $=$ (thymus weight $/$ weight before euthanasia) $\times 100 \%$; Splenic index $=($ spleen weight $/$ weight before euthanasia) $\times 100 \%$.

\section{Results}

The effect of $B A$ on growth performance. In terms of ADFI, no significant difference was found between the four groups $(\mathrm{P}>0.05)$. During weeks $0-4$, ADG was significantly higher in the three treatment groups than in the control group $(\mathrm{P}<0.05)$, and $\mathrm{ADG}$ was significantly higher in treatment
Determination of serum immune markers. At the end of the experiment, 4 experimental rabbits were randomly selected from each group, and blood was collected via cardiac puncture into $5 \mathrm{~mL}$ tubes. Blood samples were centrifuged at 3,000 r/min for $5 \mathrm{~min}$, and supernatants were transferred to new tubes and stored at $-20^{\circ} \mathrm{C}$. Serum concentrations of immunoglobulin (Ig) G, IgM, complement 3 (C3) and $\mathrm{C} 4$ were determined by the immunoturbidimetric assay (ZHAO and JIANG, 2006).

Statistical analysis. Statistical analysis was performed using the SPSS18.0 software (SPSS Inc., Chicago, Illinois, USA). Single and multiple comparisons were performed using one-way analysis of variance (ANOVA) and Duncan's test, respectively. Data are expressed as mean $\pm \mathrm{SD}$ and $\mathrm{P}<0.05$ was considered statistically significant.

groups II and III than in treatment group I $(\mathrm{P}<0.05)$. During weeks 5-8, ADG was significantly higher in the three treatment groups than in the control group $(\mathrm{P}<0.05)$. During the entire experimental period (weeks 0-8), ADG was significantly higher in treatment groups II and III than in treatment

Table 2. The effect of BA on the growth performance of meat rabbits.

\begin{tabular}{|c|c|c|c|c|}
\hline \multirow{2}{*}{ Items } & \multicolumn{3}{|c|}{ Treatment groups } & III \\
\hline ADFI (g/d) & I & II & Control group \\
\hline $0-4$ week & $96.98 \pm 3.96$ & $97.71 \pm 4.03$ & $98.12 \pm 4.62$ & $97.16 \pm 4.28$ \\
\hline $5-8$ week & $134.23 \pm 3.28$ & $135.61 \pm 4.88$ & $134.91 \pm 4.78$ & $134.29 \pm 5.22$ \\
\hline $0-8$ week & $115.87 \pm 4.68$ & $116.66 \pm 4.56$ & $116.51 \pm 5.12$ & $115.22 \pm 6.48$ \\
\hline ADG (g/d) & $32.02 \pm 0.21^{\mathrm{b}}$ & $33.26 \pm 0.37^{\mathrm{c}}$ & $33.68 \pm 0.49^{\mathrm{c}}$ & $30.29 \pm 0.19^{\mathrm{a}}$ \\
\hline $0-4$ week & $30.18 \pm 0.31^{\mathrm{b}}$ & $31.20 \pm 0.42^{\mathrm{b}}$ & $31.27 \pm 0.21^{\mathrm{b}}$ & $28.58 \pm 0.49^{\mathrm{a}}$ \\
\hline $5-8$ week & $31.18 \pm 0.15^{\mathrm{b}}$ & $32.29 \pm 0.28^{\mathrm{c}}$ & $32.42 \pm 0.23^{\mathrm{c}}$ & $29.36 \pm 0.52^{\mathrm{a}}$ \\
\hline $0-8$ week & $3.01 \pm 0.03^{\mathrm{b}}$ & $2.92 \pm 0.03^{\mathrm{c}}$ & $2.91 \pm 0.02^{\mathrm{c}}$ & $3.18 \pm 0.05^{\mathrm{a}}$ \\
\hline F/G (g/g) & $4.43 \pm 0.08^{\mathrm{b}}$ & $4.38 \pm 0.06^{\mathrm{b}}$ & $4.31 \pm 0.04^{\mathrm{b}}$ & $4.62 \pm 0.13^{\mathrm{a}}$ \\
\hline $0-4$ week & $3.70 \pm 0.06^{\mathrm{b}}$ & $3.60 \pm 0.05^{\mathrm{c}}$ & $3.58 \pm 0.07^{\mathrm{c}}$ & $3.91 \pm 0.08^{\mathrm{a}}$ \\
\hline $5-8$ week & \multicolumn{5}{|c|}{} \\
\hline $0-8$ week & \multicolumn{5}{|c|}{}
\end{tabular}

a-c: Means in the same row with no common superscripts differ significantly $(\mathrm{P}<0.05)$. ADG, average daily gain; ADFI, average daily feed intake; $\mathrm{F} / \mathrm{G}$, feed to gain ratio. 
H. Zhang et al.: Effect of B. amyloliquefaciens on weaned meat rabbits

Table 3. The effect of BA on the immune organ index of meat rabbits

\begin{tabular}{|l|c|c|c|c|}
\hline \multirow{2}{*}{ Items } & \multicolumn{3}{|c|}{ Treatment groups } & \multirow{2}{*}{ Control group } \\
\cline { 2 - 5 } & I & II & III & $4.58 \pm 0.39^{\mathrm{a}}$ \\
\hline Thymus weight $(\mathrm{g})$ & $5.02 \pm 0.61^{\mathrm{a}}$ & $6.18 \pm 0.59^{\mathrm{b}}$ & $6.56 \pm 0.67^{\mathrm{b}}$ & $1.45 \pm 0.42^{\mathrm{a}}$ \\
\hline Spleen weight $(\mathrm{g})$ & $1.51 \pm 0.37^{\mathrm{a}}$ & $1.93 \pm 0.38^{\mathrm{b}}$ & $2.01 \pm 0.26^{\mathrm{b}}$ & $1.81 \pm 0.22^{\mathrm{a}}$ \\
\hline Thymic index $(\mathrm{g} / \mathrm{kg})$ & $2.03 \pm 0.38^{\mathrm{a}}$ & $2.36 \pm 0.26^{\mathrm{b}}$ & $2.45 \pm 0.21^{\mathrm{b}}$ & $0.57 \pm 0.12^{\mathrm{a}}$ \\
\hline Splenic index $(\mathrm{g} / \mathrm{kg})$ & $0.59 \pm 0.21^{\mathrm{ab}}$ & $0.72 \pm 0.16^{\mathrm{ab}}$ & $0.76 \pm 0.15^{\mathrm{b}}$ & \\
\hline
\end{tabular}

${ }^{\mathrm{a}-\mathrm{b}}$ :Means in the same row with no common superscripts differ significantly $(\mathrm{P}<0.05)$.

Table 4. The effect of BA on the immune function of meat rabbits

\begin{tabular}{|l|c|c|c|c|}
\hline \multirow{2}{*}{ Items } & \multicolumn{3}{|c|}{ Treatment groups } & \multirow{2}{*}{ Control group } \\
\cline { 2 - 5 } & I & II & III & $4.66 \pm 1.02$ \\
\hline IgG(mg/dL) & $4.71 \pm 0.36$ & $4.89 \pm 0.46$ & $4.87 \pm 0.51$ & $0.28 \pm 0.05^{\mathrm{a}}$ \\
\hline $\mathrm{IgM}(\mathrm{mg} / \mathrm{dL})$ & $0.38 \pm 0.06^{\mathrm{ab}}$ & $0.46 \pm 0.05^{\mathrm{b}}$ & $0.46 \pm 0.02^{\mathrm{b}}$ & $0.14 \pm 0.03^{\mathrm{a}}$ \\
\hline $\mathrm{C} 3(\mathrm{mg} / \mathrm{dL})$ & $0.15 \pm 0.01^{\mathrm{a}}$ & $0.21 \pm 0.02^{\mathrm{b}}$ & $0.22 \pm 0.01^{\mathrm{b}}$ & $0.02 \pm 0.01^{\mathrm{a}}$ \\
\hline $\mathrm{C} 4(\mathrm{mg} / \mathrm{dL})$ & $0.03 \pm 0.01^{\mathrm{a}}$ & $0.05 \pm 0.01^{\mathrm{b}}$ & $0.05 \pm 0.01^{\mathrm{b}}$ & $0.05)$. \\
\hline
\end{tabular}

${ }^{\mathrm{a}-\mathrm{b}}$ :Means in the same row with no common superscripts differ significantly $(\mathrm{P}<0.05)$.

group I and the control group $(\mathrm{P}<0.05)$, and ADG was significantly higher in treatment group I than in the control group $(\mathrm{P}<0.05)$ (Table 2).

During weeks $0-4, \mathrm{~F} / \mathrm{G}$ was significantly higher in the control group than in the three treatment groups $(\mathrm{P}<0.05)$, and significantly higher in treatment group I than in treatment groups II and III $(\mathrm{P}<0.05)$. During weeks 5-8, F/G was significantly higher in the control group than in the three treatment groups $(\mathrm{P}<0.05)$ but similar between the three treatment groups $(\mathrm{P}>0.05)$. During the entire experimental period (weeks 0-8), F/G was significantly higher in the control group than in the three treatment groups $(\mathrm{P}<0.05)$, and was significantly higher in treatment group I than in treatment groups II and III $(\mathrm{P}<0.05)$ (Table 2).

The effect of BA on immune organ index and immune function. Compared with the control group, the weights of the thymus and spleen were significantly higher in treatment groups II and III $(\mathrm{P}<0.05)$, but no significant difference was found in treatment group I $(\mathrm{P}>0.05)$. Similarly, compared with the control group, the thymic index was significantly higher in treatment groups II and III $(\mathrm{P}<0.05)$, but not significantly in treatment group I $(\mathrm{P}>0.05)$ (Table 3).
Compared with the control group, the splenic index was significantly higher in treatment group III $(\mathrm{P}<0.05)$, but no significant difference was observed in treatment groups I and II $(\mathrm{P}>0.05)$ (Table 3 ). In addition, no significant difference was found in serum $\operatorname{IgG}$ level between the four groups $(\mathrm{P}>0.05)$. However, serum IgM, C3, and C4 levels were significantly higher in treatment groups II and III than in the control group $(\mathrm{P}<0.05)$ (Table 4$)$.

\section{Discussion}

In this study, our results showed that BA had little effect on the ADFI but it increased the growth performance of weaned meat rabbits by improving ADG and reducing F/G. In addition, these effects were significantly higher as the dose of BA supplementation increased, demonstrating that the positive effect of BA on the growth performance of weaned rabbits was dependent on a certain quantity, which was consistent with the findings in broilers (AHMED et al., 2014; WANG et al., 2018). Upon entrance into the digestive tract of weaned rabbits, BA creates an anaerobic environment by microbial oxygen consumption, and provides a niche for the substantial proliferation of microbial species that produce xylan-degrading enzymes, pectinolytic 
enzymes and mucolytic enzymes (TROCINO et al., 2005; CAO et al., 2018; TSUKAHARA et al., 2018). This effect enhances the absorption of nutrients, and thereby improves the growth performance of weaned rabbits. Furthermore, since animals are under stress before and after weaning, and undergo major changes in their intestinal enzyme system, the benefit of BA on the growth performance of preweaning and weaned rabbits may be attributable to the rapid establishment of an enzyme system in weaned rabbits that is able to reduce the effect of weaning stress (ALEXOPOULOS et al., 2004; AYYAT et al., 2018).

Our findings demonstrated that BA supplementation in the daily diet increased the weight of the immune organs in weaned rabbits, and the thymic and splenic indexes were significantly higher in treatment group III than in the control group. This result is consistent with previous studies, where Bacillus significantly increased the thymic and splenic indexes of broiler chicks and weaned piglets, and actively promoted the growth and development of immune organs (ZHANG et al., 2005; XIN et al., 2011). These effects may be related to the antigenic or adjuvant properties of various components of the Bacillus, including cell wall sugar, peptidoglycan, peptides and proteins, that constantly stimulate the intestinal mucosa or act on immune organs to promote their growth and development (VITETTA et al., 2017). In addition, Bacillus may produce or synthesize various nutrients in the animal's gastrointestinal tract that are required for the growth and development of the immune organs (TROCINO et al., 2005).

Immunoglobulins are the major immune mediator of the humoral immune response, and play an important role in the defense system of the animal. IgG is a key indicator for the overall humoral immune status of the body (SEBINA and PEPPER, 2018). Bacillus subtilis supplementation significantly increases serum IgG levels in broiler chicks, but has no effect on IgM levels (YU et al., 2010). Moreover, another study demonstrated that Bacillus licheniformis significantly increases local IgG and IgM levels in the respiratory and digestive tract of broiler chicks (YANG et al., 2005). Our findings are somewhat similar but slightly different from the above results, and this might be attributable to the different animal species or probiotic products. Nonetheless, our study confirmed that BA had a certain humoral immunity-promoting effect in meat rabbits.

The complement system is a key component of the immune system and is involved in defense response and immune regulation. The biological functions of the complement are dependent on its activation. C3 plays a critical role in the process of complement activation, and $\mathrm{C} 4$ is important for the activation phase of the complement (FU et al., 2018). As a result, serum $\mathrm{C} 3$ and $\mathrm{C} 4$ levels are biomarkers for assessing immune status. Our results showed that BA at high dose significantly increased levels of $\mathrm{C} 3$ and $\mathrm{C} 4$, which is consistent with the findings of a previous study, which showed that Bacillus can significantly increase serum levels of C3 and C4 in grass carp (SHEN et al., 2011).

\section{Conclusions}

Supplementation with an appropriate amount of BA in the diet could effectively improve the growth performance, immune organ index, and immune function of weaned New Zealand rabbits.

\section{Acknowledgement}

This study was supported by the National Natural Science Foundation of China (81903282).

\section{References}

AHMED, S. T., M. ISLAM, H. S. MUN, H. J. SIM, Y. J. KIM, C. J. YANG (2014): Effects of Bacillus amyloliquefaciens as a probiotic strain on growth performance, cecal microflora, and fecal noxious gas emissions of broiler chickens. Poult. Sci. 93, 1963-1971.

DOI: $10.3382 /$ ps.2013-03718

ALEXOPOULOS, C., I. E. GEORGOULAKIS, A. TZIVARA, S. K. KRITAS, A. SIOCHU, S. C. KYRIAKIS (2004): Field evaluation of the efficacy of a probiotic containing Bacillus licheniformis and Bacillus subtilis spores, on the health status and performance of sows and their litters. J. Anim. Physiol. Anim. Nutr. (Berl). 88, 381-392.

DOI: 10.1111/j.1439-0396.2004.00492.x

AYYAT, M. S., A. A. AL-SAGHEER, K. M. ABD EL-LATIF, B. A. KHALIL (2018): Organic selenium, probiotics, and prebiotics effects on growth, blood biochemistry, and carcass traits of growing rabbits during summer and winter seasons. Biol. Trace Elem. Res. 186, 162-173.

DOI: $10.1007 / \mathrm{s} 12011-018-1293-2$ 
BARTON, M. D (2000): Antibiotic use in animal feed and its impact onhuman health. Nutr. Res. Rev. 13, 279-299.

DOI: $10.1079 / 095442200108729106$

CAO, G. T., X. A. ZHAN, L. L. ZHANG, X. F. ZENG, A. G. CHEN, C. M. YANG (2018): Modulation of broilers' caecal microflora and metabolites in response to a potential probiotic Bacillus amyloliquefaciens. J. Anim. Physiol. Anim. Nutr. (Berl). 102, 909-917.

DOI: $10.1111 /$ jpn. 12856

COGLIANI, C., H. GOOSSENS, C. GREKO (2011): Restricting antimicrobialuse in food animals: lessons from Europe. Microbes 6, 274-279.

DOI: $10.1128 /$ microbe.6.274.1

De BLAS, C., G. G. MATEOS (1998): Feed Formulation. In: The Nutrition of the Rabbit (De Blas, C., J. Wiseman, Eds.). CABI Publishing, New York, NY, USA. 241-253.

DOWARAH, R., A. K. VERMA, N. AGARWAL (2017): The use of Lactobacillus as an alternative of antibiotic growth promoters in pigs: A review. Anim. Nutr. 3, 1-6.

DOI: 10.1016/j.aninu.2016.11.002

FU, Y. W., C. K. ZHU, Q. Z. ZHANG (2018): Molecular characterization and expression analysis of complement component $\mathrm{C} 3$ in southern catfish (Silurus meridionalis) and a whole mount in situ hybridization study on its ontogeny. Fish Shellfish Immunol. 84, 865-875.

DOI: $10.1016 /$ j.fsi.2018.10.083

GADDE, U., W. H. KIM, S. T. OH, H. S. LILLEHOJ (2017): Alternatives to antibiotics for maximizing growth performance and feed efficiency in poultry: a review. Anim. Health Res. Rev. 18, 26-45.

DOI: $10.1017 / \mathrm{S} 1466252316000207$

GAO, P., C. MA, Z. SUN, L. WANG, S. HUANG, X. SU, J. XU, H. ZHANG (2017): Feed-additive probiotics accelerate yet antibiotics delay intestinal microbiota maturation in broiler chicken. Microbiome. 5, 91.

DOI: $10.1186 / \mathrm{s} 40168-017-0315-1$

GIBSON, G. R., R. HUTKINS, M. E. SANDERS, S. L. PRESCOTT, R. A. REIMER, S. J. SALMINEN, K. SCOTT, C. STANTON, K. S. SWANSON, P. D. CANI, K. VERBEKE, G. REID (2017): Expert consensus document: The international scientific Association forProbiotics and Prebiotics (ISAPP) consensus statement on thedefinition and scope of prebiotics. Nat. Rev. Gastroenterol. Hepatol. 14, 491-502.

DOI: $10.1038 /$ nrgastro.2017.75

GUO, J. R., X. F. DONG, S. LIU, J. M. TONG (2018): Highthroughput sequencing reveals the effect of Bacillus subtilis CGMCC 1.921 on the cecal microbiota and gene expression in ileum mucosa of laying hens. Poult. Sci. 97, 2543-2556.

DOI: $10.3382 / \mathrm{ps} /$ pey 112

LI, S., Y. ZHOU, Z. MIAO (2017): Prevalence and antibiotic resistance of non-typhoidal salmonella isolated from raw chicken carcasses of commercial broilers and spent hens in Tai'an, China. Front. Microbiol. 8, 2106.

DOI: $10.3389 /$ fmicb.2017.02106

LUTFUL KABIR, S. M (2009): The role of probiotics in the poultry industry. Int. J. Mol. Sci. 10, 3531-3546.

DOI: 10.3390/ijms10083531

NATIONAL RESEARCH COUNCIL (1977): Nutrient Requirements of Rabbits. Washington, DC. National Academy of Science, p. 30.

PARK, Y. H., F. HAMIDON, C. RAJANGAN, K. P. SOH, C. Y. GAN, T. S. LIM, W. N. ABDULLAH, M. T. LIONG (2016): Application of probiotics for the production of safeand high-quality poultry meat. Korean J. Food Sci. Anim. Resour. 36, 567-576.

DOI: $10.5851 /$ kosfa.2016.36.5.567

SAMOLINSKA, W., E. KOWALCZUK-VASILEV, E. R. GRELA (2018): Comparative effect of different dietary inulin sources and probiotics on growth performance and blood characteristics in growing-finishing pigs. Arch. Anim. Nutr. 72, 379-395.

DOI: $10.1080 / 1745039 X .2018 .1505147$

SEBINA, I., M. PEPPER (2018): Humoral immune responses to infection: common mechanisms and unique strategies to combat pathogen immune evasion tactics. Curr. Opin. Immunol. 51, 46-54.

DOI: $10.1016 /$ j.coi.2018.02.001

SHEN, W. Y., W. F. LI, Q. LIANG, B. DENG, N. N. CHEN, X. X. ZHOU (2011): Effects of Bacillus subtilis on growth, immunity and antioxidation in grass carp. Chin. J. Anim. Nutr. 23, 881-886 (in Chinese).

TROCINO, A., G. XICCATO, L. CARRARO, G. JIMENEZ (2005): Effect of diet supplementation with Toyocerin (Bacillus cereus var. Toyoi) on performance and health of growing rabbits. World Rabbit Sci. 13, 17-28.

TSUKAHARA, T., R. INOUE, K. NAKAYAMA, T. INATOMI (2018): Inclusion of Bacillus amyloliquefaciens strain TOA5001 in the diet of broilers suppresses the symptoms of coccidiosis by modulating intestinal microbiota. Anim. Sci. J. 89, 679-687.

DOI: $10.1111 /$ asj. 12980

VITETTA, L., E. T. SALTZMAN, M. THOMSEN, T. NIKOV, S. HALL (2017): Adjuvant probiotics and the intestinal microbiome: enhancing vaccines and immunotherapy outcomes. Vaccines (Basel) 5, 50.

DOI: $10.3390 /$ vaccines5040050

WANG, Y., Y. WANG, H. XU, X. MEI, L. GONG, B. WANG, W. LI, S. JIANG (2018): Direct-fed glucose oxidase and its combination with $B$. amyloliquefaciens SC06 on growth performance, meat quality, intestinal barrier, antioxidative status, and immunity of yellow-feathered broilers. Poult. Sci. 97, 3540-3549.

DOI: $10.3382 /$ ps/pey216 
XIN, N., Q. Y. DIAO, N. F. ZANG, M. ZHOU (2011): Effects of Bacillus on growth performance, immune organ index and gastrointestinal $\mathrm{pH}$ of weaned piglets. Feed Indust. 32, 33-36 (in Chinese).

YANG, Y., P. MCHOCT (2009): Dietary modulation of gut microflora inbroiler chickens: a review of the role of six kinds of alternatives toin-feed antibiotics. World's Poultry Sci. J. 65, 97-114.

DOI: $10.1017 / \mathrm{s} 0043933909000008$

YANG, Y. R., S. M. ZHENG, J. LIU, C. Q. MA (2005): Dynamic changes of relative content of immunoglobulins in local humor and immune organ index of chicks administrated with probiotic. Chin. J. Anim. Vet. Sci. 36, 352-356 (in Chinese).
YU, D. Y., X. F. MAO, Y. QIN, W. F. LI (2010): Effects of $B$. subtilis on growth performance, antioxidant and immunity of broilers. Chin. J. Anim. Sci. 46, 22-25 (in Chinese).

ZHANG, F., K. C. PAN, S. M. RU (2005): Effect of Bacillus on red blood cells of immune organs of broiler chicks. Chin. J. Vet. Med. 41, 9-10 (in Chinese).

ZHAO, Y., J. JIANG (2006): Concentration of immunoglobulin in animal serum determined by using immunoturbidimetric assay. China Feed. 5, 25-28 (in Chinese).

ZOU, F., D. ZENG, B. WEN, H. SUN, Y. ZHOU, M. YANG, Z. PENG, S. XU, H. WANG, X. FU, D. DU, Y. ZENG, H. ZHU, K. PAN, B. JING, P. WANG, X. NI (2016): Illumina Miseq platform analysis caecum bacterial communities of rex rabbits fed with different antibiotics. AMB Express 6, 100. DOI: $10.1186 / \mathrm{s} 13568-016-0273-1$

Received: 11 December 2018

Accepted: 23 December 2019

\section{ZHANG, H., J. LIU, Z. MIAO: Učinak probiotika Bacillus amyloliquefaciens na prirast, imunološki indeks organa i imunološki status kunića za meso nakon odbića. Vet. arhiv 90, 271-277, 2020. \\ SAŽETAK}

Pokazalo se da bakterije roda Bacillus mogu poboljšati proizvodna svojstva i imunost pilića i svinja, pa je pretpostavka ovog rada da bi Bacillus amyloliquefaciens (BA) mogao učinkovito povećati prirast i imunološku sposobnost kunića za meso nakon odbića. S tom svrhom, istražen je učinak BA-a na prirast, imunološki indeks organa i imunološki status kunića mesne pasmine. Ukupno 160 kunića novozelandske pasmine nakon odbića (35 \pm 3 dana), slučajnim je odabirom, podijeljeno u 4 skupine s 4 ponavljanja po skupini $(n=10$ po ponavljanju, 5 mužjaka i 5 ženki). Kunići iz kontrolne skupine dobivali su osnovni obrok, dok je kunićima u pokusnim skupinama I, II i III u osnovni obrok dodavano 150, 300 i $450 \mathrm{mg} / \mathrm{kg}$ BA-a, ukupno osam tjedana. Rezultati su pokazali da je dodatak BA-a povećao dnevni prirast i smanjio konverziju hrane. Osim toga dodatak BA-a znakovito je povećao imunološke indekse slezene i timusa te razinu imunoglobulina M (IgM), komplementa 3 (C3) i 4 (C4) u pokusnim skupinama II i III (P < 0,05). Zaključeno je da bi dodavanje BA-a u obrok kunića za meso nakon odbića moglo doprinijeti povećanju njihova prirasta, imunološkog indeksa organa i imunološkog statusa.

Ključne riječi: Bacillus amyloliquefaciens; meso kunića; prirast; imunološki indeks organa; imunološki status 
